\title{
LEADING IN THE TIME OF CRISIS: CHARISMATIC LEADERSHIP
}

\author{
Ana Radulovići ${ }^{1 *}$ \\ Olga Epitropaki², \\ Antonis Polentas ${ }^{3}$, \\ Miquel Salvadó-Gracia ${ }^{4}$ \\ ${ }^{1}$ Singidunum University, \\ Belgrade, Serbia \\ 2Durham University, \\ United Kingdom \\ ${ }^{3} \mathrm{PhD}$ candidate, Ionian University, \\ Corfu, Greece \\ ${ }^{4} \mathrm{PhD}$ candidate, University of \\ Duisburg - Essen, \\ Duisburg, Federal Republic of \\ Germany
}

Correspondence:

Ana Radulović

e-mail:

aradulovic@singidunum.ac.rs

\begin{abstract}
:
The global economy, as well as our health and social behaviour seem to be significantly affected by the COVID-19 pandemic. Considering the influence that leaders have on followers, distribution of resources and policies, the study of leadership seems to be an important tool for facing crisis situations. This paper reviews charismatic leadership theory and in particular outlines verbal and nonverbal tactics of charismatic leadership. The paper outlines empirical findings that show the impact of charismatic leaders on various outcomes.
\end{abstract}

Keywords:

charismatic leadership, crisis.

\section{INTRODUCTION}

Leadership is viewed as one of the most important and complex phenomena in social sciences. It is commonly defined as a process through which leaders aim to influence their followers in order to achieve a common purpose (Stogdill, 1974). The outbreak of COVID-19 pandemic during 2020 had a tremendous impact on our lives, our social interactions, and the global economy. During pandemic, the importance of a leader's influence became pronounced, especially the impact that political leaders may have on citizens' adoption of precautionary measures (Antonakis, 2021). Indeed, leaders control resources and create policies that affect the manner in which society functions (Abrams, Lalot, \& Hogg, 2021). Through their communication, leaders are able to coordinate the efforts of individuals and help resolve public crisis situations, alongside scientists' efforts (Antonakis, 2021). One of the theories that was highly researched in order to explain the leader effectiveness is charismatic leadership (Murphy \& Ensher, 2008). Leaders could have a large effect on individuals either directly (Antonakis, d'Adda, Weber, \& Zehnder, 2014) or via social media (Tur, Harstad, \& Antonakis, 2021). The aim of this paper is to provide an overview of charismatic leadership theory and in particular to focus on charismatic leadership tactics (Antonakis, Bastardoz, Jacquart, \& Shamir, 2016; Antonakis, Fenley, \& Liechti, 2011). The paper outlines empirical findings that demonstrate the impact of charismatic leaders on various outcomes. In particular, the paper highlights the findings of a recent study which showed that the extent to which the speeches of the US Governors during COVID crisis were perceived to be charismatic had an influence on citizens' behaviours that save lives, namely social distancing (Jensen et al., 2021). 


\section{CHARISMATIC LEADERSHIP}

Initially, charismatic leadership was employed to explain the features of political or religious leaders. Later it became a component of transformational leadership (e.g., Bass, 1998). This and other theoretical frameworks suggest that charismatic leadership positively impacts group and organizational performance, subordinate efforts, satisfaction with job and motivation. Charismatic leadership is not only reserved for managers at the highest organizational levels but could be found at different organizational levels. Initially, the word charisma was used to portray an individual's ability to do exceptional things. Weber (1947) viewed charisma as someone's extraordinary power, almost of divine origin, that make this individual be treated and accepted as a leader. Over the years several authors have offered their conceptualizations of charismatic leadership.

House (1977) identified personality characteristics and behaviours that have charismatic impact on their followers. In his view, charismatic leaders are dominant and willing to influence others, have strong moral values and are highly self-confident. Regarding their behaviours, charismatic leaders are strong role model for their followers. For instance, Gandhi was the epitome of civil insurgence through his advocacy of nonviolence. Furthermore, charismatic leaders demonstrate competence to their subordinates. Moreover, charismatic leaders communicate strong moral goals for their followers, such as the ones expressed in Martin Luther King Jr.'s "I Have a Dream" speech. Additionally, they set high expectations and reassure their followers that they are competent to achieve them. Also, charismatic leaders motivate followers by triggering their esteem, affiliation or power, as did John F. Kennedy in his famous utterance that every American should identify what they can do for their country and not vice versa.

House (1977) also argued that charismatic leadership directly affects followers' trust in the leader, followers' approval of the leader and the overlap between the followers' and the leader's principles. Other effects include compliance, devotion to the leader, identification with the leader, emotional involvement in leader's vision, and belief that they possess the ability to achieve it. These effects tend to occur in critical situations because the leaders enable followers to overcome various struggles and removes the threats.

In their model, Conger and Kanungo (1994) conceptualize leaders in an organisational context and suggest that charismatic leaders engage in six behaviours. These behaviours include: developing strategic vision, communicating, considering the environment, demonstrating unconventional behaviours, taking personal risk, being sensitive to the needs of organisational members, and challenging the status quo. With these behaviours, charismatic leaders facilitate change in their organisations. Namely, leaders examine the environment of their organisations in order to identify potential obstacles and opportunities. This enables them to devise a vision for their organisation and convey it to the organisational members. Frequently, this vision will deviate from the current organisational practices (i.e., the status quo) and may involve taking personal risks. Behaviours that the charismatic leader engage in are often viewed as eccentric, such as quirky speech. Nevertheless, when leading their organisations, charismatic leaders consider the needs of their subordinates (Conger \& Kanungo, 1994).

Shamir, House, and Arthur (1993) offered a distinct conceptualization of the charismatic leadership theory. In their view, charismatic leaders alter subordinates' selfconcepts and in doing so subordinates' identity becomes linked to the organisation's collective identity. Charismatic leaders achieve this by placing an emphasis on intrinsic rewards and by reducing the importance of extrinsic rewards. Furthermore, charismatic leaders convey high expectations to their subordinates, allow them to express themselves through work, and enhance their self-efficacy. In doing so, charismatic leaders link subordinates' selfconcepts to the organisational identity.

\section{TACTICS OF CHARISMATIC LEADERSHIP}

Neocharismatic theorists perceive charisma as something that can be examined across various organisational contexts (Antonakis \& House, 2013), and focus on its immediate rather than distant expressions. In particular, they focus on charismatic leaders in organisations who use symbolic power and ideological values to influence their followers. According to the neocharismatic scholars (e.g., Antonakis et al., 2011), leaders are perceived to be charismatic if they can communicate passionately and powerfully and unite followers to act upon a vision. Charismatic leaders use influencing tactics that involve both the verbal content but also their nonverbal delivery. In doing so, they are able to impact both subordinates' emotions and cognition.

Antonakis and Atwater (2002) proposed that charismatic leaders use nine verbal and three nonverbal strategies. One of the verbal tactics involves the use of metaphors through which leaders influence how subordinates comprehend and frame the content of the message. Indeed, metaphorical meanings simplify the point, trigger emotions, and facilitate recollection (Mio, Riggio, Levin, \& Reese, 2005). Charismatic leaders often relay on stories to simplify the message, make it memorable and facilitate identification with the protagonists. 
Furthermore, charismatic leaders state their moral beliefs and understand the feelings of the group which enables them to be viewed as a group representative (Hogg, 2001). Moreover, they devise superior expectations for their subordinates and express confidence that those could be achieved (House, 1977). Consequently, these tactics enhance subordinates' motivation and self-efficacy beliefs. Lastly, charismatic leaders use several techniques to focus subordinates' attention on their narrative. In particular, they use contrasts to frame and emphasise the message. Additionally, charismatic leaders use lists to convey the sense of wholeness. Finally, charismatic leaders pose rhetorical questions to their followers to create puzzles that need to be resolved (Antonakis et al., 2011).

Regarding nonverbal tactics, charismatic leaders effectively communicate their positive and negative emotions to express their passion and gain support for their messages (Bono \& Ilies, 2006). Another nonverbal tactic involves the use of body movements and facial expressions and modulations in their voice tone. The application of both verbal and nonverbal tactics makes the leader's point more memorable (Antonakis \& Atwater, 2002).

\section{OUTCOMES OF CHARISMATIC LEADERSHIP TACTICS}

Empirical studies have shown that followers are motivated by charisma. Antonakis et al. (2014) conducted a field study and a set of laboratory experiments to examine whether leader's charisma, manifested as a motivational speech, can trigger individuals to engage in socially beneficial activities. The field experiment showed that the subordinates who were exposed to charismatic speech increase their output by $17 \%$ compared to the subordinates who were exposed to a regular speech. These results were replicated in laboratory experiments in which participants were exposed to motivational speeches before playing game of public goods. Indeed, the presence of charismatic elements in the leader' speech resulted in 19\% increase in participant contributions. The effects of charisma on individual performance were recently replicated in a field experiment (Meslec, Curseu, Fodor, \& Kenda, 2020). Namely, it was found that the effect of charisma was manifested via vision dimension of leadership.

Antonakis et al. (2011) used experimental studies to show that charisma could be taught. Namely, results demonstrate that the training had significant impact on evaluations of leader charisma, and that charisma, in turn, had significant impact on evaluations of leader emergence and prototypicality. The authors argue that the organisations should consult evidence-based research before designing training and development programmes (Antonakis et al., 2011).
A recent study used data collected on social media to examine the impact of charisma for informal leaders, the individuals who communicate their beliefs and preferences to others but have no formal power over them (Tur et al., 2021). The authors evaluated the sample of TED presentations and tweets and highlighted the objective indicators of charisma. The results showed that the individuals who used more verbal charismatic tactics had higher views of their TED talks which were also found to be more uplifting, beyond nonverbal cues and attractiveness. These individuals also had more retweets (Tur et al., 2021).

\section{CHARISMATIC LEADERSHIP IN THE TIME OF CRISIS}

Even though a number of empirical studies have shown the positive effects on individual and group outcomes in organisations, a recent study examined the extent to which charisma of political leaders could influence individual behaviour during a pandemic, and thus save lives of the citizens. Jensen et al. (2021) conducted a study using anonymised mobility data of the US citizens. Charisma was objectively evaluated in COVID speeches given by the US Governors. Interestingly, the extent to which the leader was perceived to be charismatic was linked to the decline of citizens' geographical mobility which is believed to contribute to the spreading of SARS-CoV-2.

The first study used 350 press briefing addresses regarding COVID given by all 50 US Governors and combined that data with the social distancing behaviour of citizens collected anonymously via their smart phones. The results imply that conservative citizens may be responsive to charismatic communication, in particular (Jensen et al., 2021). Even though this study was conducted in the context of political leadership, the results correspond to the findings of organisational studies which showed the effects of charismatic communication tactics on individuals (e.g., Meslec et al., 2020).

The second study was designed as a laboratory experiment that involved 661 US participants in which Governor charisma was manipulated in a vignette. The study aimed to examine factors regarding an individual's decision to engage in physical distancing behaviour (Jensen et al., 2021). The results showed that conservatives tend to respond more to Governors' charismatic features. This influences their beliefs whether their countrymen will engage in physical distancing which seems to affect their behaviour, as well. Liberals, on the other hand, were not influenced by charisma, since they were willing to engage in physical distancing behaviours irrespective of the tactics directed at them. The authors emphasize that leaders can learn how to be more charismatic or improve their charismatic tendencies which enables them to have more 
impact on the followers, especially when some individuals need additional motivation to engage in particular behaviours. Therefore, charismatic communication style of political leaders could have a direct impact on the number of saved lives during a pandemic (Jensen et al., 2021).

\section{CONCLUSION}

Crisis situations such as the outbreak of COVID-19 pandemic provide a favourable milieux for the emergence of charismatic leadership. Leaders do have a significant impact on followers' beliefs, values, and behaviour. This paper outlined some of the most recent findings regarding the effects that charismatic leaders may have on subordinates, especially in the political context during pandemic. In order to be effective the leaders need to be charismatic and good communicators and these skills can be acquired and improved over time (Antonakis et al., 2011; Antonakis, Fenley, \& Liechti, 2012). Therefore, charismatic leadership seems to be an important tool for facing crises.

\section{LITERATURE}

Abrams, D., Lalot, F., \& Hogg, M. A. (2021). Intergroup and intragroup dimensions of COVID-19: A social identity perspective on social fragmentation and unity. Group Processes \& Intergroup Relations, 24(2), 201-209.

Antonakis, J. (2021). Leadership to defeat COVID-19. Group Processes \& Intergroup Relations, 24(2), 210-215.

Antonakis, J., \& Atwater, L. (2002). Leader distance: A review and a proposed theory. The Leadership Quarterly, 13(6), 673-704.

Antonakis, J., Bastardoz, N., Jacquart, P., \& Shamir, B. (2016). Charisma: An ill-defined and ill-measured gift. Annual Review of Organizational Psychology and Organizational Behavior, 3, 293-319.

Antonakis, J., d'Adda, G., Weber, R., \& Zehnder, C. (2014). Just words? Just speeches? On the economic value of charismatic leadership. NBER Rep, 4.

Antonakis, J., Fenley, M., \& Liechti, S. (2011). Can charisma be taught? Tests of two interventions. Academy of Management Learning \& Education, 10(3), 374-396.

Antonakis, J., Fenley, M., \& Liechti, S. (2012). Learning charisma. Transform yourself into the person others want to follow. Harvard Business Review, 90(6), 127-130, 147.

Antonakis, J., \& House, R. J. (2013). The full-range leadership theory: The way forward Transformational and charismatic leadership: The road ahead 10th anniversary edition: Emerald Group Publishing Limited.

Bass, B. M. (1998). The ethics of transformational leadership. In J. B. Ciulla (Ed.), Ethics, the heart of leadership (pp. 169-192). Wesrport, CT: Praeger
Bono, J. E., \& Ilies, R. (2006). Charisma, positive emotions and mood contagion. The Leadership Quarterly, 17(4), 317-334.

Conger, J. A., \& Kanungo, R. N. (1994). Charismatic leadership in organizations: Perceived behavioral attributes and their measurement. Journal of Organizational Behavior, 15(5), 439-452.

Hogg, M. A. (2001). A social identity theory of leadership. Personality and Social Psychology Review, 5(3), 184-200.

House, R. J. (1977). A 1976 theory of charismatic leadership. In J. G. Hunt \& L. L. Larson (Eds.), Leadership: The cutting edge (pp. 189-207). Carbondale: Southern Illinois Univesrity Press.

Jensen, U., Rohner, D., Bornet, O., Carron, D., Garner, P., Loupi, D., \& Antonakis, J. (2021). Combating COVID-19 with Charisma: Evidence on Governor Speeches and Physical Distancing in the United States. doi: https://doi.org/10.31234/osf.io/ypqmk

Meslec, N., Curseu, P. L., Fodor, O. C., \& Kenda, R. (2020). Effects of charismatic leadership and rewards on individual performance. The Leadership Quarterly, 31(6), 101423.

Mio, J. S., Riggio, R. E., Levin, S., \& Reese, R. (2005). Presidential leadership and charisma: The effects of metaphor. The Leadership Quarterly, 16(2), 287-294.

Murphy, S. E., \& Ensher, E. A. (2008). A qualitative analysis of charismatic leadership in creative teams: The case of television directors. The Leadership Quarterly, 19(3), 335-352.

Shamir, B., House, R. J., \& Arthur, M. B. (1993). The motivational effects of charismatic leadership: A self-concept based theory. Organization Science, 4(4), 577-594.

Stogdill, R. M. (1974). Handbook of leadership: A survey of the literature. New York: Free Press.

Tur, B., Harstad, J., \& Antonakis, J. (2021). Effect of charismatic signaling in social media settings: Evidence from TED and Twitter. The Leadership Quarterly, 101476.

Weber, M. (1947). The theory of social and economic organization. New York: Free Press. 